\title{
B3 - ANÁLISE DE RISCO EM METODOLOGIA ANALÍTICA DE CONTROLE DE QUALIDADE DE BIOFÁRMACO ALFAINTERFERONA 2B
}

\author{
Cleyton Lage Andrade ${ }^{1}$, Elezer Monte Blanco Lemes ${ }^{1}$,
}

1. Instituto de Tecnologia em Imunobiológicos, Bio-Manguinhos/Fiocruz, Rio de Janeiro, Brasil.

Objetivos: Neste trabalho, nossa proposta foi estabelecer uma metodologia alternativa para o controle de qualidade do biofármaco IFN $\alpha$-2b utilizando como metodologia a ferramenta de análise de risco, Análise de Perigos e Pontos Críticos de Controle (HACCP).

Métodos: A análise de produtos biotecnológicos baseia-se no uso de métodos analíticos sofisticados para demonstrar sua identidade estrutural, homogeneidade de proteínas e avaliar sua vida útil ou estabilidade. Embora não haja relatos de efeitos adversos para a saúde pelo DNA do hospedeiro no produto intermediário de produtos biotecnológicos, as agências regulatórias tem requerido às indústrias a garantia de que o nível de DNA neles seja o menor possível. A técnica comumente utilizada pelo CIGB para quantificar níveis de DNA é o dot-blot radioativo. No entanto, vários fatores tornam impraticável seu uso na rotina dos laboratórios analíticos: é trabalhoso, demorado, semi-quantitativo e requer um radioisótopo. Para determinar essas pequenas quantidades de DNA, um método analítico deve ser extremamente sensível e robusto. Em princípio, três técnicas têm a sensibilidade requerida: a hibridização, os métodos baseados em ligação de DNA e proteína (como o Threshold) e o PCR quantitativo. A Gestão de Riscos para Qualidade (GRQ) é um processo sistemático para avaliação, controle, comunicação e análise de riscos para a qualidade do produto (medicamento) em todo seu ciclo de vida. O gerenciamento de riscos auxilia na decisão, levando em consideração as incertezas, a possibilidade de circunstâncias ou eventos futuros e seus efeitos sobre os objetivos acordados. A GRQ apoia uma abordagem científica e prática para a tomada de decisões e podem avaliar e gerenciar riscos utilizando ferramentas próprias. A partir disso, foi escolhido o HACCP como ferramenta da GRQ para a avaliação dos riscos/perigos de cada abordagem escolhida para compará-las. 
Resultados: Foram observados 25 perigos para o dot-blot nas oito etapas do ensaio, 14 perigos nas cinco etapas do qPCR e 19 perigos nas cinco etapas do Threshold. Vários desses perigos, nos respectivos ensaios, apresentam causas, efeitos, detecção e medidas de mitigação semelhantes. Verificou-se que o e dot-blot radioativo é o ensaio que apresenta maior número de pontos críticos de controle (PCC) devido a sua natureza radiativa, 16 no total. Logo após vem o qPCR com seis PCC em três etapas seguido do Threshold com cinco PCC estando quatro em uma única etapa, o que evidencia que a alta criticidade da etapa e que muitas medidas de mitigação precisam ser implementadas para que o ensaio esteja dentro dos padrões de controle de uso na rotina dos laboratórios.

Conclusão: A partir da análise dos perigos pelo uso do HACCP, concluiu-se que a metodologia analítica alternativa melhor avaliada para a questão proposta é o qPCR. 